\title{
Optimum Reactor Outlet Temperatures for High Temperature Gas-Cooled Reactors Integrated with Industrial Processes
}

The INL is a

U.S. Department of Energy National Laboratory

operated by

Battelle Energy Alliance

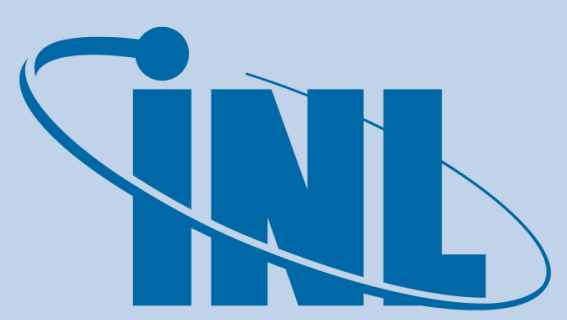

Idaho National Laboratory

April 2011

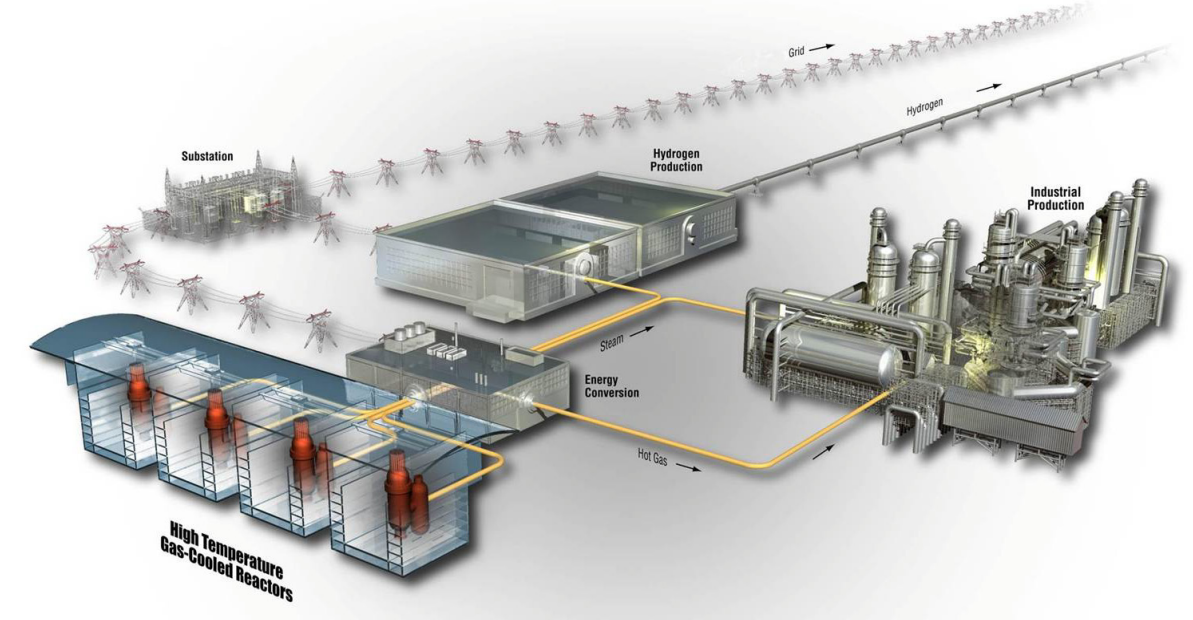




\section{DISCLAIMER}

This information was prepared as an account of work sponsored by an agency of the U.S. Government. Neither the U.S. Government nor any agency thereof, nor any of their employees, makes any warranty, expressed or implied, or assumes any legal liability or responsibility for the accuracy, completeness, or usefulness, of any information, apparatus, product, or process disclosed, or represents that its use would not infringe privately owned rights. References herein to any specific commercial product, process, or service by trade name, trade mark, manufacturer, or otherwise, does not necessarily constitute or imply its endorsement, recommendation, or favoring by the U.S. Government or any agency thereof. The views and opinions of authors expressed herein do not necessarily state or reflect those of the U.S. Government or any agency thereof. 


\title{
Optimum Reactor Outlet Temperatures for High Temperature Gas-Cooled Reactors Integrated with Industrial Processes
}

\author{
Lee 0 Nelson \\ Anastasia Gandrik \\ Michael McKellar \\ Michael Patterson \\ Eric Robertson \\ Rick Wood
}

April 2011

\begin{abstract}
Idaho National Laboratory
Next Generation Nuclear Plant Project

Idaho Falls, Idaho 83415
\end{abstract}

Prepared for the

U.S. Department of Energy

Office of Nuclear Energy

Under DOE Idaho Operations Office

Contract DE-AC07-05ID14517 

Next Generation Nuclear Plant Project

\section{Optimum Reactor Outlet Temperatures for High Temperature Gas-Cooled Reactors Integrated with Industrial Processes}

INL/EXT-11-21537

April 2011

Approved by:

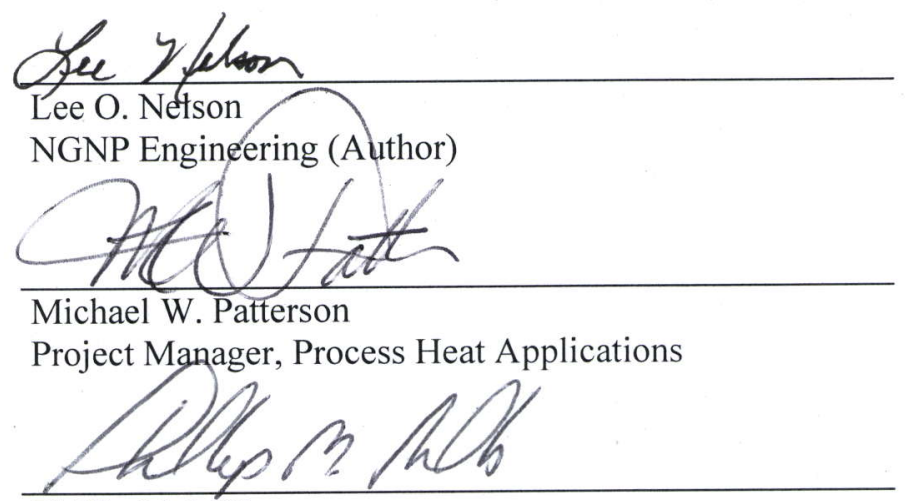

Phillip M. Mills

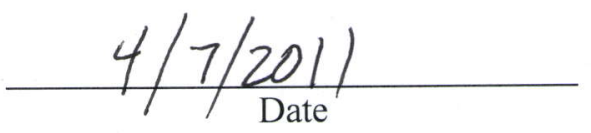

Director, NGNP Engineering
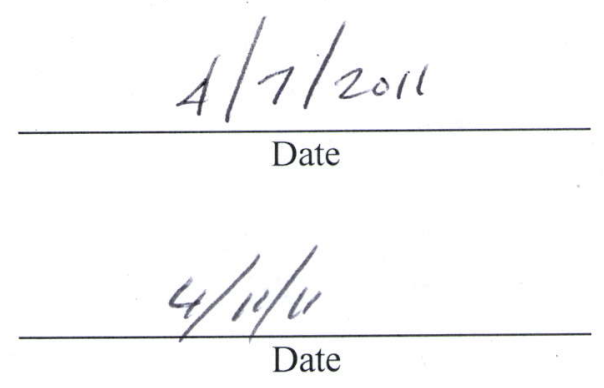



\begin{abstract}
This report summarizes the results of a temperature sensitivity study conducted to identify the optimum reactor outlet temperature for generating the primary and secondary outputs from a high temperature gas-cooled reactor. This study assumed that the primary output of the reactor was steam delivered at $17 \mathrm{MPa}$ and $540^{\circ} \mathrm{C}$ or helium delivered at $7 \mathrm{MPa}$ and $625-925^{\circ} \mathrm{C}$. The secondary output was electricity or hydrogen. For the power generation analysis, it was assumed that the power cycle efficiency was $66 \%$ of the maximum theoretical efficiency of the Carnot thermodynamic cycle. Hydrogen was generated via the high-temperature steam electrolysis or the steam methane reforming process. The study indicates that the optimum reactor outlet temperatures for the primary and secondary outputs vary from 750 to $950^{\circ} \mathrm{C}$ depending on which process is coupled to the reactor and depending on specific end user needs. Additional study is recommended to identify the optimum reactor outlet temperatures for the process evaluations that were developed for high temperature gas-cooled reactorintegrated production of synthetic transportation fuels, ammonia, and ammonia derivatives, oil from unconventional sources, and substitute natural gas from coal.
\end{abstract}




\section{SUMMARY}

Under direction from the Department of Energy (DOE), the Next Generation Nuclear Plant (NGNP) Project has evaluated the integration of high temperature gas-cooled reactor (HTGR) technology with industrial processes. The evaluations showed that HTGR-integrated processes will reduce the carbon dioxide and other greenhouse gas emissions that are generated by conventional processes, primarily by replacing the heat derived from natural gas and coal combustion with high-temperature process heat from the HTGR.

The detailed process models developed for HTGR-integrated production of synthetic transportation fuels and ammonia and the recovery of unconventional oils were based on a reactor outlet temperature (ROT) of $750^{\circ} \mathrm{C}$, the temperature at which the NGNP is expected to operate. This report summarizes the results of the temperature sensitivity study conducted to identify the optimum ROTs for producing the heat and hydrogen required by these industrial processes.

The study assumed that the outputs of an HTGR were steam delivered at $17 \mathrm{MPa}$ and $540^{\circ} \mathrm{C}$ and helium delivered at $7 \mathrm{MPa}$ and $625-925^{\circ} \mathrm{C}$. The secondary outputs of the HTGR were electricity and hydrogen. For the power generation analysis, it was assumed that the power cycle efficiency was $66 \%$ of the maximum theoretical efficiency of the Carnot thermodynamic cycle. Hydrogen was generated via the high-temperature steam electrolysis or the steam methane reforming process.

The analysis for process heat showed that the helium or steam returning from the industrial process must be within a specific temperature range to maintain the correct reactor inlet temperature and to best utilize the heat generated by the HTGR. For example, the temperature of steam returning from an industrial process cannot exceed the temperature of saturated liquid water because it needs to be pumped back to the steam generator. Because of this constraint, the optimum HTGR ROT for generating steam at $540^{\circ} \mathrm{C}$ and $17 \mathrm{MPa}$ is $770^{\circ} \mathrm{C}$. The optimum HTGR ROT for high-temperature helium depends on the needs of the industrial process being supplied by the high-temperature helium.

The evaluation shows that the optimum HTGR ROT for electricity production is $950^{\circ} \mathrm{C}$, for hydrogen production via $\mathrm{HTSE}$ is $850^{\circ} \mathrm{C}$, and for hydrogen production via steam methane reforming is $875^{\circ} \mathrm{C}$.

The results of the temperature sensitivity study indicate that optimum ROTs or a range of ROTs could be identified to further refine the process evaluations developed for HTGR-integrated production of synthetic transportation fuels, ammonia and ammonia derivatives, oil from unconventional sources, and substitute natural gas from coal. These evaluations were initially based on an HTGR ROT of $750^{\circ} \mathrm{C}$. The results of the preliminary temperature sensitivity analysis for processes that utilize the primary and secondary HTGR outputs are shown in Figure ES-1.

Additional modeling is required to provide a more precise estimate of the optimum ROTs, but the exact optimum for each process is expected to be bound by the ranges shown in the figure. The optimum HTGR ROT for processes that use high-temperature helium is approximately $35^{\circ} \mathrm{C}$ higher than the maximum process temperature range to account for the two heat exchangers located between the HTGR and the process. The optimum HTGR ROT for processes that utilize steam is $770^{\circ} \mathrm{C}$.

The study reached the following conclusions:

- The optimum HTGR ROTs for steam generation (delivered at $540^{\circ} \mathrm{C}$ and $17 \mathrm{MPa}$ ), electricity generation, hydrogen production via high temperature steam electrolysis, and hydrogen production via steam methane reforming are $770,950,850$, and $875^{\circ} \mathrm{C}$ respectively.

- The optimum HTGR ROT for steam production varies depending on the temperature and pressure of the steam produced. 


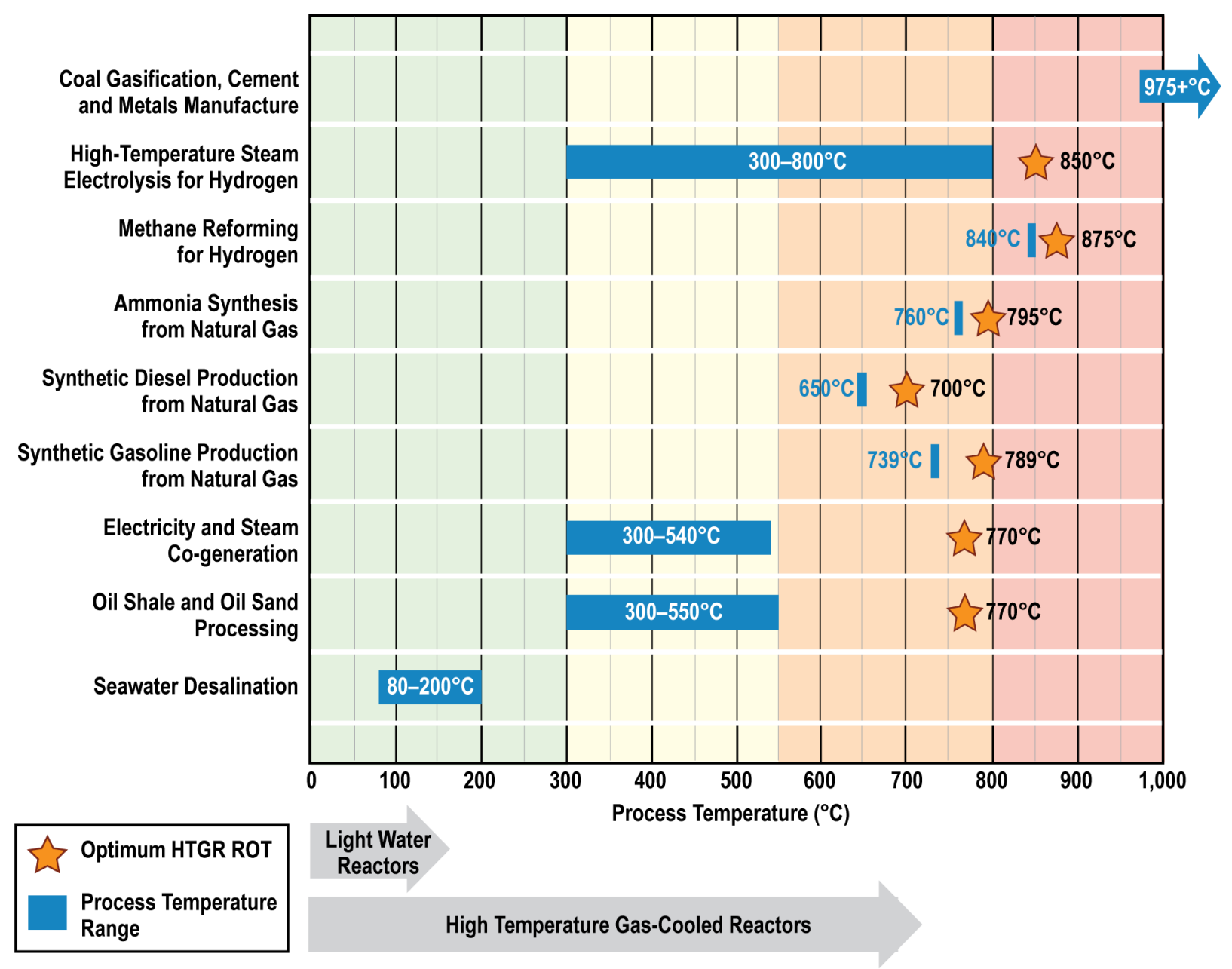

Figure ES-1. Optimum HTGR ROTs and the process temperature range associated with HTGR-integrated industrial processes.

- The optimum HTGR ROT for process heat delivered as helium (or other hot gas) does not exist, because the optimum is process dependent.

- Because this study was based solely on mass and energy balance information, economic analyses are required to identify more realistic optimum HTGR ROTs.

- In order to perform an economic analysis, the HTGR cost as a function of configuration, size, and temperature is required.

- Based on a preliminary high-level analysis, the optimum HTGR ROT for hydrogen production, ammonia synthesis from natural gas, production of synthetic fuels from natural gas, cogeneration of electricity and steam, and oil shale and oil sand processing varies from 750 to $950^{\circ} \mathrm{C}$. Additional study is required to identify a more precise optimum HTGR ROT for these processes.

Based on the results of this study it is recommended that a temperature sensitivity study be conducted for the processes shown in Figure ES-1 that includes the impact of economic considerations. To adequately address economic considerations, it is recommended that a cost model be developed for the HTGR to include the impact of HTGR configuration, size, and $750-950^{\circ} \mathrm{C}$ HTGR ROT on the HTGR capital and operations and maintenance cost. 


\section{CONTENTS}

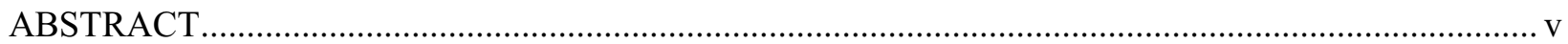

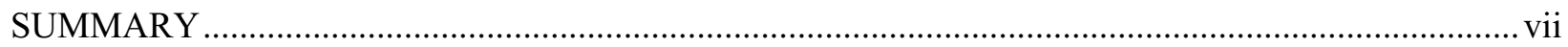

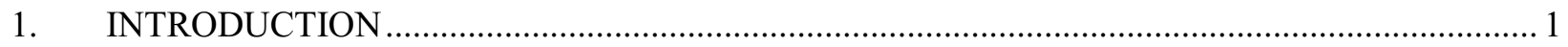

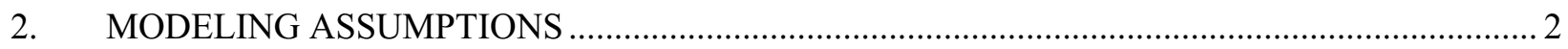

3. APPROACH

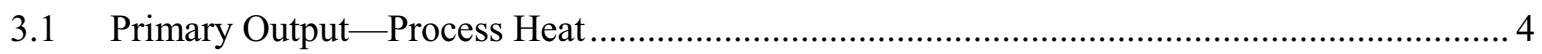

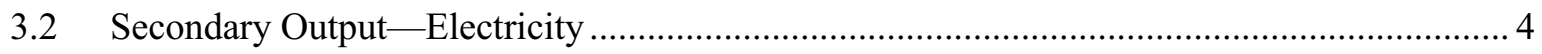

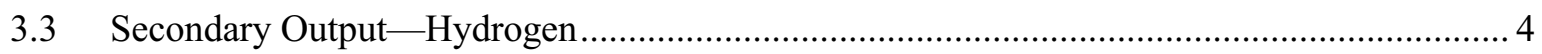

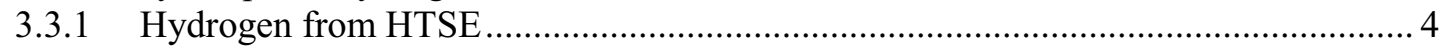

3.3.2 Hydrogen from Steam Methane Reforming ......................................................... 4

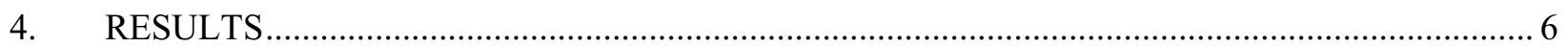

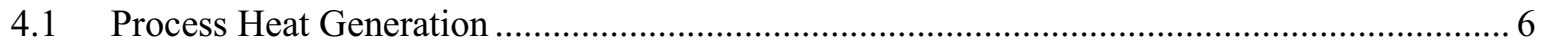

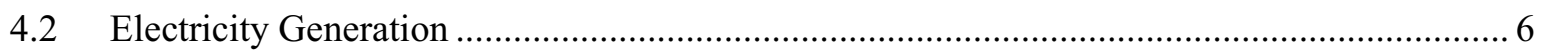

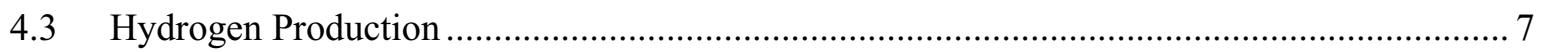

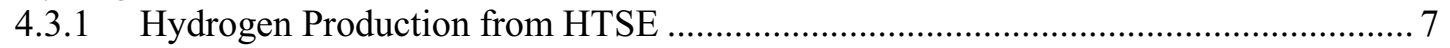

4.3.2 Hydrogen Production via Steam Methane Reforming ............................................ 8

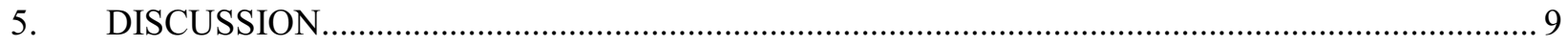

5.1 Implications of Optimum ROTs on HTGR-Integrated Industrial Processes ........................ 9

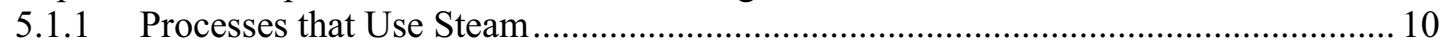

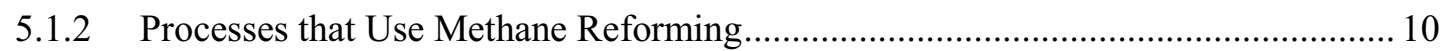

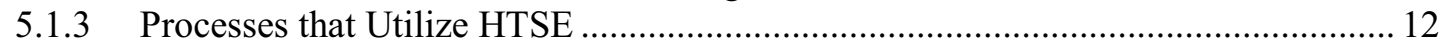

5.1.4 Summary—Optimum HTGR ROT for Industrial Processes.................................... 13

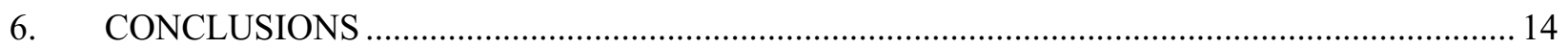

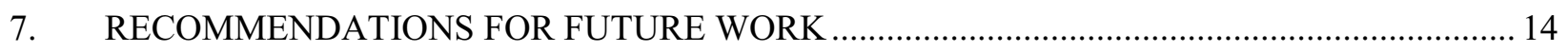

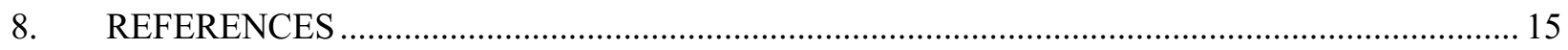

\section{FIGURES}

Figure ES-1. Optimum HTGR ROTs and the process temperature range associated with HTGRintegrated industrial processes............................................................................................. viii

Figure 1. Schematic diagram illustrating an HTGR reactor pressure vessel and accompanying intermediate heat exchanger or steam generator................................................................ 2

Figure 2. Electricity generation from heat produced in an HTGR .......................................................... 4

Figure 3. HTGR-integrated hydrogen production via HTSE.............................................................. 5

Figure 4. HTGR-integrated hydrogen production via steam methane reforming. ..................................... 5 
Figure 5. Simplified block flow diagram for a conventional natural gas-to-diesel process plant.

Figure 6. Simplified block flow diagram for an HTGR-integrated natural gas-to-synthetic diesel industrial process plant.

Figure 7. Optimum HTGR ROTs and the process temperature range associated with HTGRintegrated industrial processes.

\section{TABLES}

Table 1. Primary and secondary outputs from a 600-MW(t) HTGR. 2

Table 2. Assumptions used to calculate the primary and secondary outputs of an HTGR as the ROT varies from $650-950^{\circ} \mathrm{C}$.

Table 3. Process heat (steam at $540^{\circ} \mathrm{C}$ and $17 \mathrm{MPa}$; helium at $7 \mathrm{MPa}$ ) delivered as a function of HTGR ROT.

Table 4. HTGR electricity generation efficiency as a function of HTGR ROT. 7

Table 5. Calculated hydrogen production from HTGR-integrated HTSE as a function of ROT.

Table 6. Hydrogen production rate from HTGR-integrated steam methane reforming over a range of ROTs. Outputs from a conventional steam methane reforming process are shown as a basis for comparison. .8

Table 7. Optimum ROTs for primary and secondary outputs from an HTGR. 9

Table 8. Preliminary implications of the optimum HTGR ROTs required to produce steam and generate electricity for oil and bitumen recovery.

Table 9. Highest assumed temperature provided with a maximum HTGR ROT of $750^{\circ} \mathrm{C}$ for processes that use methane reforming to produce synthetic diesel, synthetic gasoline, and ammonia derivatives.

Table 10. The optimum HTGR ROTs for processes that use coal and use heat and hydrogen from HTSE for synthetic diesel, synthetic gasoline, and substitute natural gas production..... 


\section{Optimum Reactor Outlet Temperatures for High Temperature Gas-Cooled Reactors Integrated with Industrial Processes}

\section{INTRODUCTION}

Under Department of Energy (DOE) direction, the Next Generation Nuclear Plant (NGNP) Project has evaluated the integration of high temperature gas-cooled reactor (HTGR) technology with industrial processes. After potential applications were identified in an initial survey, ${ }^{1}$ detailed models based on typical plant production capacities were developed and comprehensive evaluations were conducted for the following processes $2,3,4,5,6,7,8$ :

- Synthetic gasoline production from coal and natural gas

- Synthetic diesel production from coal and natural gas

- Ammonia derivatives production from natural gas

- Steam-assisted gravity drainage (SAGD) for bitumen recovery from oil sands

- Oil production from oil shale

- Substitute natural gas production from coal.

The evaluations showed that HTGR-integrated processes will reduce carbon dioxide and other greenhouse gas emissions generated by conventional processes, primarily by replacing the heat derived from natural gas and coal combustion with high-temperature process heat from the HTGR. HTGRintegrated processes will also prolong the availability of limited natural resources so they can be directed toward more valuable uses, such as using natural gas as a petrochemical feedstock.

The detailed models developed for these HTGR-integrated industrial processes (see References 2-8) were based on an ROT of $750^{\circ} \mathrm{C}$, the temperature at which the NGNP is expected to operate.

Temperature sensitivity studies were conducted ${ }^{9,10,11,12,13,14,15,16,17}$ to identify the optimum reactor outlet temperatures (ROTs) for producing the heat, electricity, and hydrogen. This report summarizes the modeling assumptions used in these studies (Section 2), approach (Section 3), affects of varying the ROT from $650-950^{\circ} \mathrm{C}$ on the primary and secondary outputs (Section 4), implications for HTGR-integrated industrial processes (Section 5), and overall conclusions and recommendations for future work (Section 6). 


\section{MODELING ASSUMPTIONS}

The primary output of an HTGR is heat, which requires a steam generator or intermediate heat exchanger downstream of the HTGR to supply the heat as high-temperature steam, helium, or other fluid. Secondary outputs - electricity, hydrogen, and oxygen - can be provided when additional equipment is added downstream. The potential outputs from a 600-MW(t) HTGR are described in Table 1. A schematic diagram of an HTGR reactor and accompanying steam generator and intermediate heat exchanger pressure vessel is shown in Figure 1.

Table 1. Primary and secondary outputs from a 600-MW(t) HTGR.

\section{Primary Outputs}

\section{Description}

High-temperature process heat
- Helium
- $\quad 625-900^{\circ} \mathrm{C}(7-9.1 \mathrm{MPa})$
- Steam
- $540^{\circ} \mathrm{C}(17 \mathrm{MPa})$

Secondary Outputs

\section{Description}

Electricity Generated by a Rankine, Brayton, or combined Brayton/Rankine power cycle

Hydrogen $\left(\mathrm{H}_{2}\right)$ and oxygen $\left(\mathrm{O}_{2}\right) \quad$ Produced by high-temperature steam electrolysis (HTSE)

Hydrogen $\left(\mathrm{H}_{2}\right) \quad$ Produced by steam methane reforming

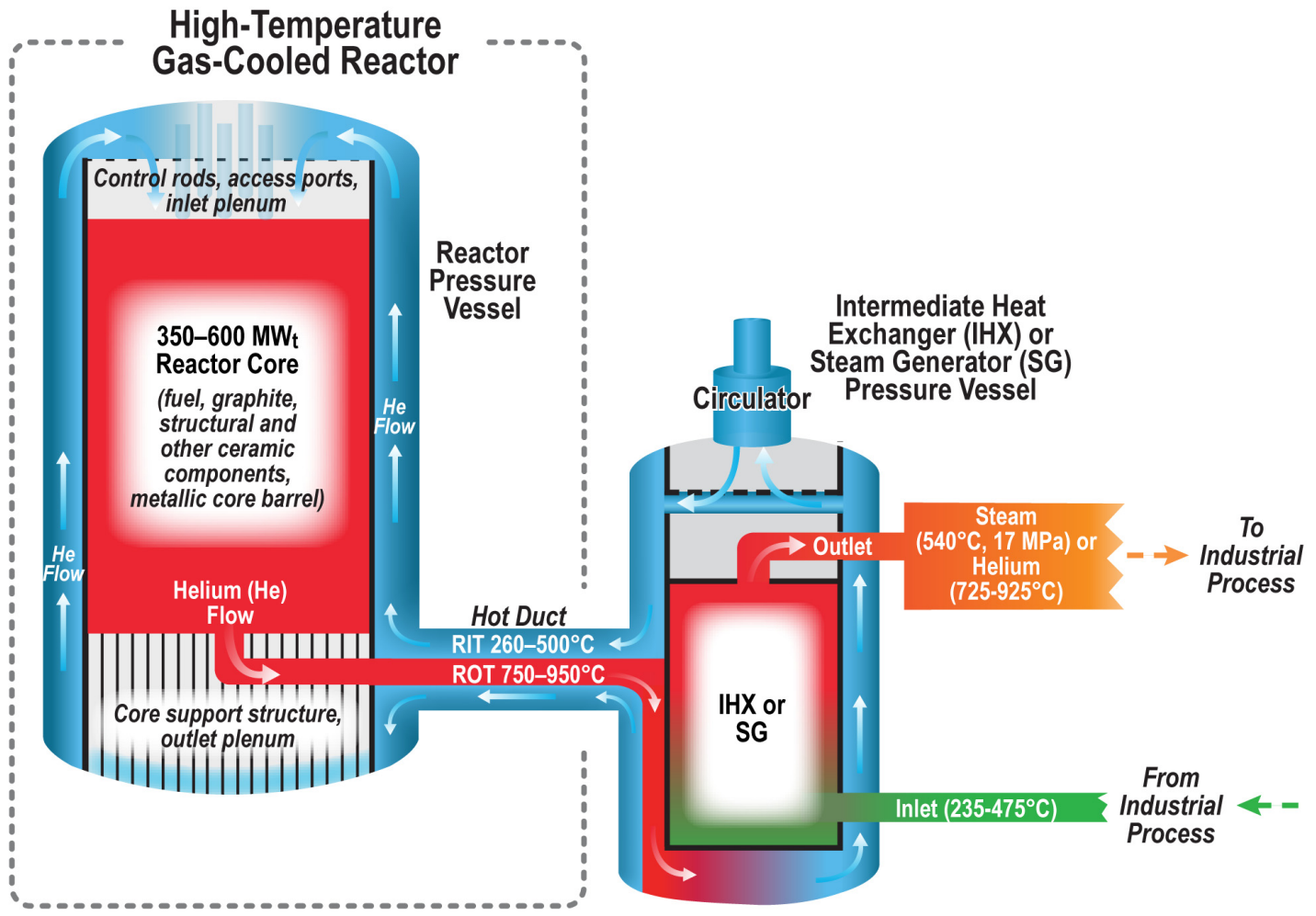

Figure 2. Schematic diagram illustrating an HTGR reactor pressure vessel and accompanying intermediate heat exchanger or steam generator. 


\section{APPROACH}

The INL has performed a significant amount of analysis for a variety of customers over the past several years. These efforts required the development of an extensive library of conventional process models of petrochemical plants, which are kept up to date to accurately reflect current industrial processes. The work described in this section was developed from the existing library of process models.

\subsection{Primary Output-Process Heat}

Process heat for petrochemical and other processes can be generated by an HTGR without carbon dioxide emissions, as shown in Figure 1. Heat is provided as high-temperature helium or steam. For this analysis, the steam temperature and pressure were assumed to be $540^{\circ} \mathrm{C}$ and $17 \mathrm{MPa}$, respectively. Helium was supplied at a temperature and pressure of $725-925^{\circ} \mathrm{C}$ and $7 \mathrm{MPa}$, respectively.

\subsection{Secondary Output-Electricity}

High-temperature helium or steam from an HTGR can be used by a power cycle to generate electricity, as shown in Figure 2. HTGR-generated electricity will not produce carbon dioxide emissions.

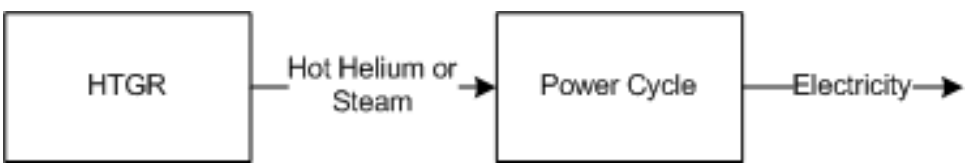

Figure 3. Electricity generation from heat produced in an HTGR.

\subsection{Secondary Output-Hydrogen}

Two methods of hydrogen production were considered: high-temperature steam electrolysis (HTSE), which uses water, heat, and electricity to generate relatively pure hydrogen and oxygen; and steam methane reforming, which uses water, heat, and methane to generate hydrogen and carbon dioxide. These processes produce some carbon dioxide emissions.

\subsubsection{Hydrogen from HTSE}

A simplified block flow diagram of the HTSE process is shown in Figure 3. The HTGR supplies high-temperature helium to both the power cycle to generate electricity for the HTSE unit and to the HTSE unit itself. If the HTGR ROT is less than $850^{\circ} \mathrm{C}$, topping heat is supplied by natural gas combustion to bring the helium to a temperature of $850^{\circ} \mathrm{C}$, the temperature needed to bring the HTSE process to the required operating temperature of $800^{\circ} \mathrm{C}$.

\subsubsection{Hydrogen from Steam Methane Reforming}

A simplified block-flow diagram of a steam methane reforming process for an HTGR-integrated plant is shown in Figure 4. The HTGR-integrated process uses high-temperature helium to provide heat for the process. However, if the HTGR ROT is less than the $850^{\circ} \mathrm{C}$ required for the process, topping heat is supplied by natural gas combustion to bring the helium to a temperature of $850^{\circ} \mathrm{C}$. 


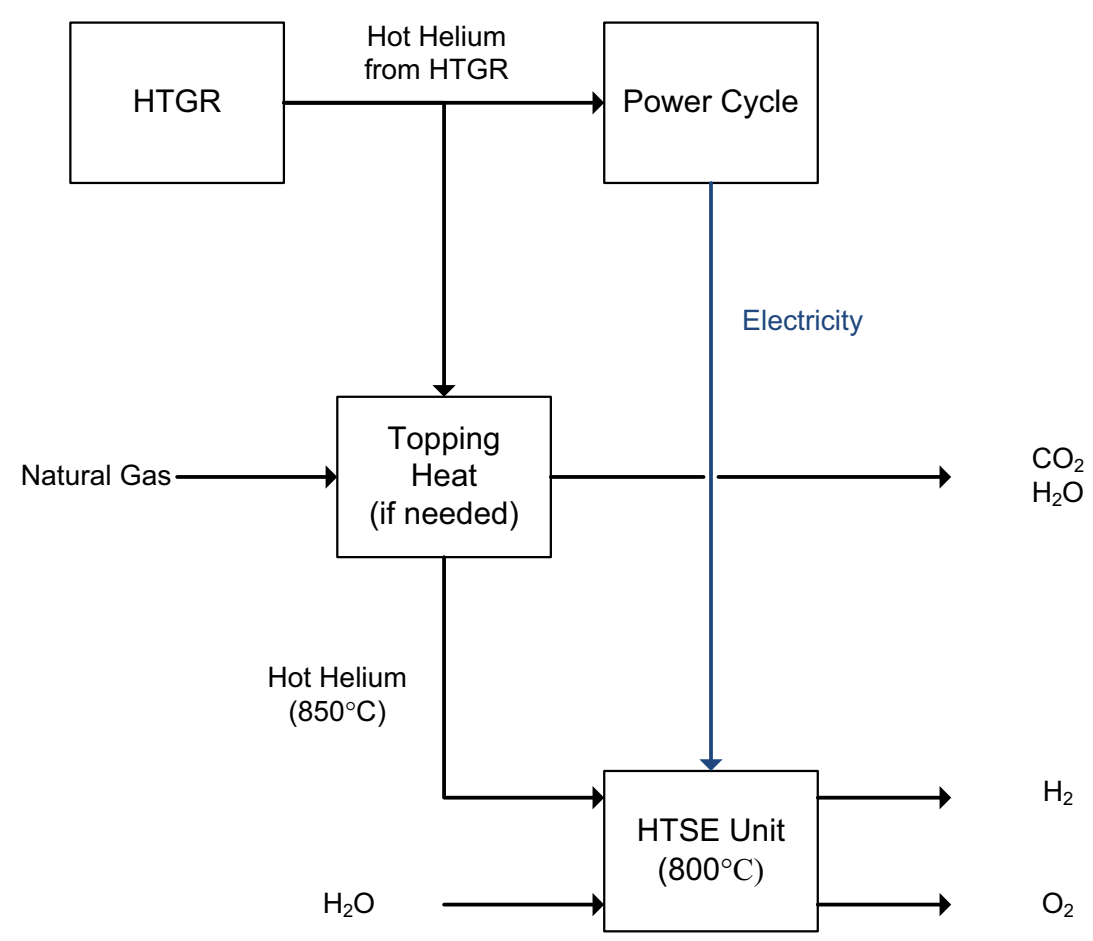

Figure 3. HTGR-integrated hydrogen production via HTSE.

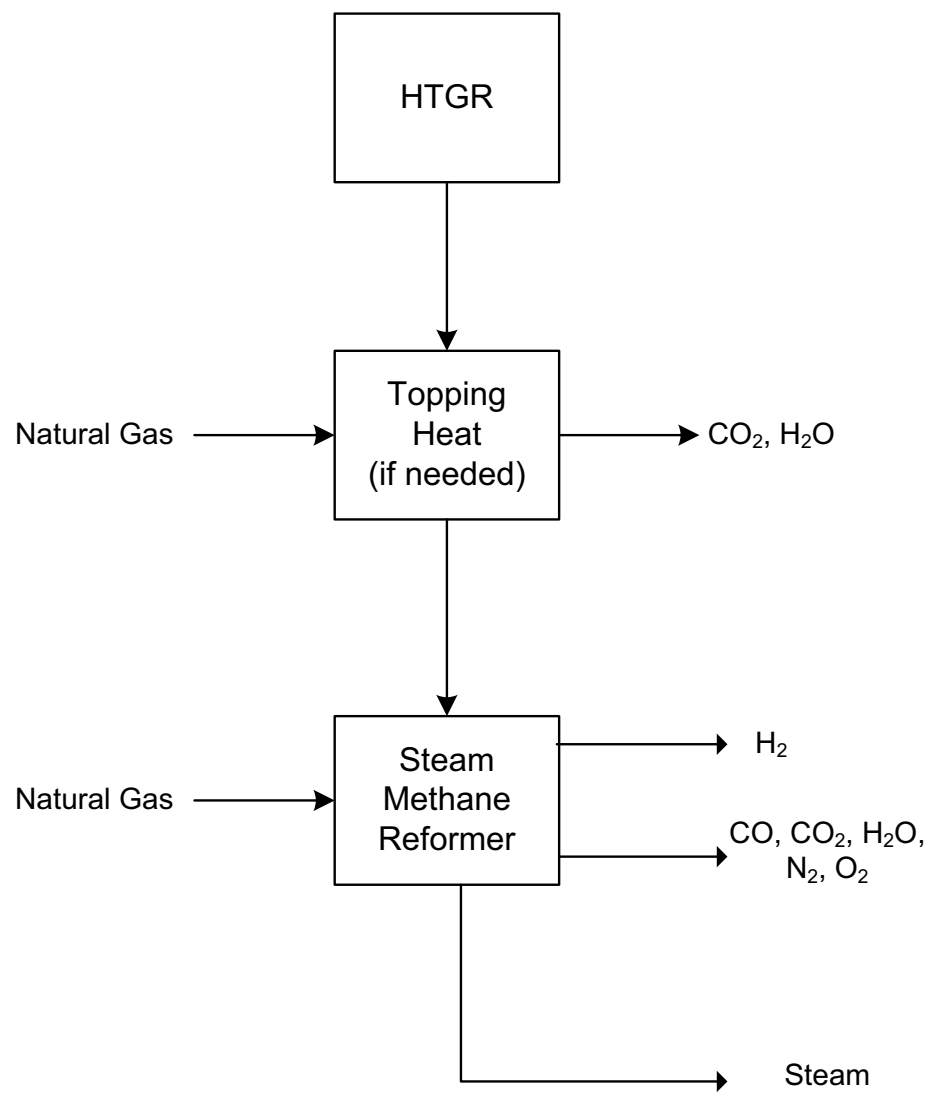

Figure 4. HTGR-integrated hydrogen production via steam methane reforming. 


\section{RESULTS}

A summary of the analyses of the various HTGR outputs - process heat, electricity, and hydrogenshows that as the HTGR ROT is increased from $650-950^{\circ} \mathrm{C}$, the quantities of the primary and secondary outputs vary. An optimum HTGR ROT was identified for each of these outputs.

\subsection{Process Heat Generation}

The analysis showed that the maximum flow rate of steam and helium varied as the HTGR ROT varied from $650-950^{\circ} \mathrm{C}$ as shown in Table 3 . This study assumed that steam is provided at a temperature of $540^{\circ} \mathrm{C}$ and $17 \mathrm{MPa}$ and helium is supplied at a pressure of $7 \mathrm{MPa}$ as follows:

- The optimum HTGR ROT for steam production was determined to be $770^{\circ} \mathrm{C}$, which is the temperature at which the steam flow rate of $402.6 \mathrm{~kg} / \mathrm{s}$ is achieved. Above $770^{\circ} \mathrm{C}$, the increase in maximum flow rate of steam is negligible because the returning liquid water temperature remains at $349.8^{\circ} \mathrm{C}$, the maximum temperature of liquid water at a pressure of $17 \mathrm{MPa}$. The optimum HGR ROT would change if a different pressure was assumed for steam delivery.

- For delivery of high-temperature helium, the optimum HTGR ROT is dependent upon the downstream process.

Table 3. Process heat (steam at $540^{\circ} \mathrm{C}$ and $17 \mathrm{MPa}$; helium at $7 \mathrm{MPa}$ ) delivered as a function of HTGR ROT.

\begin{tabular}{|c|c|c|c|c|c|c|}
\hline & \multicolumn{3}{|c|}{ Steam } & \multicolumn{3}{|c|}{ Helium } \\
\hline $\begin{array}{l}\text { HTGR } \\
\text { ROT } \\
\left({ }^{\circ} \mathrm{C}\right) \\
\end{array}$ & $\begin{array}{c}\text { Supply } \\
\text { Temperature } \\
\left({ }^{\circ} \mathrm{C}\right)\end{array}$ & $\begin{array}{l}\text { Optimum } \\
\text { RIT } \\
\left({ }^{\circ} \mathrm{C}\right) \\
\end{array}$ & $\begin{array}{c}\text { Maximum } \\
\text { Flow Rate } \\
(\mathrm{kg} / \mathrm{s})\end{array}$ & $\begin{array}{c}\text { Supply } \\
\text { Temperature } \\
\left({ }^{\circ} \mathrm{C}\right)\end{array}$ & $\begin{array}{c}\text { Optimum RIT } \\
\left({ }^{\circ} \mathrm{C}\right)\end{array}$ & $\begin{array}{c}\text { Maximum } \\
\text { Flow Rate } \\
(\mathrm{kg} / \mathrm{s}) \\
\end{array}$ \\
\hline 650 & 540 & 246.6 & 272.4 & 625 & 244.1 & 321.8 \\
\hline 700 & 540 & 294.4 & 306.1 & 675 & 283.5 & 313.9 \\
\hline 750 & 540 & 334.3 & 360.8 & 725 & 322.9 & 306.4 \\
\hline $770^{1}$ & 540 & 349.8 & 402.6 & $-^{2}$ & -2 & $-^{2}$ \\
\hline 800 & 540 & 349.8 & 402.9 & 775 & 362.3 & 299.3 \\
\hline 850 & 540 & 349.8 & 403.4 & 825 & 401.7 & 292.5 \\
\hline 900 & 540 & 349.8 & 403.9 & 875 & 441.2 & 286.0 \\
\hline 950 & 540 & 349.8 & 404.3 & 925 & 480.6 & 279.7 \\
\hline $\begin{array}{l}\text { 1. } \begin{array}{l}\text { The o } \\
\text { signif }\end{array} \\
\text { 2. } \\
\text { Calcu }\end{array}$ & $\begin{array}{l}\text { um HTGR ROT } \mathrm{f} \\
\text { tly. } \\
\text { ns for helium pro }\end{array}$ & $\begin{array}{l}\text { eam productio } \\
\text { on were not cc }\end{array}$ & $770^{\circ} \mathrm{C}$. Above & $\begin{array}{l}\text { this temperature, } \\
\text { T. }\end{array}$ & am production does 1 & t increase \\
\hline
\end{tabular}

\subsection{Electricity Generation}

The analysis showed that electricity generation efficiency improves as the HTGR ROT increases from $650-950^{\circ} \mathrm{C}$ as shown in Table 4. The optimum HTGR ROT is $950^{\circ} \mathrm{C}$ since electricity output is highest at this temperature. This study was based on incorporating a generic power cycle that generates electricity with an efficiency of $66 \%$ of the ideal Carnot cycle. ${ }^{15}$ The net electricity generation efficiency, which includes the impact from the electrical power needs of the HTGR, is the actual efficiency obtainable. 
Table 4. HTGR electricity generation efficiency as a function of HTGR ROT.

\begin{tabular}{|cc|}
\hline HTGR ROT $\left({ }^{\circ} \mathrm{C}\right)$ & Net Electricity Generation Efficiency \\
\hline $\mathbf{6 5 0}$ & $\mathbf{4 3 . 2 \%}$ \\
\hline 700 & $44.3 \%$ \\
\hline $\mathbf{7 5 0}$ & $\mathbf{4 5 . 2 \%}$ \\
\hline 800 & $46.1 \%$ \\
\hline 850 & $46.8 \%$ \\
\hline 900 & $47.5 \%$ \\
\hline $950^{*}$ & $48.2 \%$ \\
\hline * $\begin{array}{l}\text { The optimum HTGR ROT for electricity production is } 950^{\circ} \mathrm{C} \text {, below } \\
\text { which, the net electricity generation efficiency diminishes as the ROT } \\
\text { decreases from } 950-650^{\circ} \mathrm{C} \text {. }\end{array}$ \\
\hline
\end{tabular}

\subsection{Hydrogen Production}

The analysis considered HTGR-integrated hydrogen production via HTSE and steam methane reforming.

\subsubsection{Hydrogen Production from HTSE}

The analysis showed that hydrogen production from HTGR-integrated HTSE increases as the HTGR ROT increases from $650-950^{\circ} \mathrm{C}$, as shown in Table 5. The optimum ROT for delivered process heat is $850^{\circ} \mathrm{C}$ because it is the lowest temperature at which topping heat is not required. As the ROT falls below $850^{\circ} \mathrm{C}$, increasing amounts of topping heat are required to achieve the desired $800^{\circ} \mathrm{C}$ operating temperature. Because approximately $90 \%$ of the energy required to produce hydrogen is electricity, the HTSE process performs even more efficiently at $950^{\circ} \mathrm{C}$ because of the improved efficiency of generating electricity.

Table 5. Calculated hydrogen production from HTGR-integrated HTSE as a function of ROT.

\begin{tabular}{|c|c|c|c|c|c|c|}
\hline \multirow[b]{2}{*}{$\begin{array}{c}\text { HTGR } \\
\text { ROT }\left({ }^{\circ} \mathrm{C}\right)\end{array}$} & \multicolumn{3}{|c|}{ Steam Sweep HTSE } & \multicolumn{3}{|c|}{ Air Sweep HTSE } \\
\hline & $\begin{array}{l}\text { Process Heat } \\
\text { for HTSE } \\
(\mathrm{MW}(\mathrm{t}))\end{array}$ & $\begin{array}{l}\text { Hydrogen } \\
\text { Flow (kg/s) }\end{array}$ & $\begin{array}{c}\mathrm{CO}_{2} \\
\text { Emissions } \\
\left(\text { tons/day) }{ }^{\mathrm{a}}\right.\end{array}$ & $\begin{array}{l}\text { Process Heat } \\
\text { for HTSE } \\
(\mathrm{MW}(\mathrm{t}))\end{array}$ & $\begin{array}{l}\text { Hydrogen } \\
\text { Flow (kg/s) }\end{array}$ & $\begin{array}{c}\mathrm{CO}_{2} \\
\text { Emissions } \\
\text { (tons/day) }^{1} \\
\end{array}$ \\
\hline 650 & 607.3 & 1.90 & 35 & 607.7 & 1.94 & 36 \\
\hline 700 & 606.6 & 1.94 & 31 & 607.0 & 1.98 & 33 \\
\hline 750 & 605.8 & 1.97 & 27 & 606.2 & 2.02 & 29 \\
\hline 800 & 605.0 & 2.00 & 23 & 605.3 & 2.05 & 25 \\
\hline $850^{b}$ & 600.0 & 2.04 & none & 600.0 & 2.07 & none \\
\hline 900 & 600.0 & 2.07 & none & 600.0 & 2.10 & none \\
\hline $950^{c}$ & 600.0 & 2.10 & none & 600.0 & 2.12 & None \\
\hline $\begin{array}{ll}\text { a. } & \mathrm{CO}_{2} \text { emiss } \\
\text { b. } & \text { Optimum } \\
\text { c. } & \text { Optimum } \\
\end{array}$ & $\begin{array}{l}\text { ns are produced } \\
\text { TGR ROT for de } \\
\text { TGR ROT for ele }\end{array}$ & $\begin{array}{l}\text { en topping heat is } \\
\text { ered process heat } \\
\text { icity generation. }\end{array}$ & equired to bring & the HTGR ROT u & $850^{\circ} \mathrm{C}$ & \\
\hline
\end{tabular}




\subsubsection{Hydrogen Production via Steam Methane Reforming}

The analysis showed that when the natural gas flow rate is $49.2 \mathrm{MM} \mathrm{scfd,} \mathrm{more} \mathrm{hydrogen} \mathrm{is} \mathrm{produced}$ from an HTGR-integrated steam methane reforming process with an HTGR ROT of $725^{\circ} \mathrm{C}$ than from a conventional process. Furthermore, hydrogen production increases as the ROT increases to $925^{\circ} \mathrm{C}$, as shown in Table 6. Both conventional and HTGR-integrated cases emitted 3,000 tons/day of $\mathrm{CO}_{2}$.

The optimum HTGR ROT for hydrogen production is $875^{\circ} \mathrm{C}$, the temperature at which heat is best utilized for hydrogen generation rather than steam production. At higher and lower HTGR ROTs, more of the heat is used to produce steam that does not directly supply the steam methane reformer. Also, at $925^{\circ} \mathrm{C}$ compared to $875^{\circ} \mathrm{C}$, the hydrogen flow rate increases by approximately $1.5 \%$. This relatively small increase in hydrogen production does not warrant the higher ROT.

Table 6. Hydrogen production rate from HTGR-integrated steam methane reforming over a range of ROTs. Outputs from a conventional steam methane reforming process are shown as a basis for comparison.

\begin{tabular}{|lcccc|}
\hline & $\begin{array}{c}\text { HTGR ROT } \\
\left({ }^{\circ} \mathbf{C}\right)\end{array}$ & $\begin{array}{c}\text { HTGR Process } \\
\text { Heat In } \\
(\mathbf{M W}(\mathbf{t}))\end{array}$ & $\begin{array}{c}\text { Hydrogen Flow } \\
(\mathbf{k g} / \mathbf{s})\end{array}$ & $\begin{array}{c}\text { Steam } \\
\text { Production } \\
(\text { MM Btu/hr) }\end{array}$ \\
\hline $\begin{array}{l}\text { Conventional steam methane } \\
\text { reforming }\end{array}$ & NA & NA & 3.63 & 23.6 \\
& 725 & 132 & 4.10 & 199 \\
HTGR-integrated steam & 775 & 159 & 4.37 & 167 \\
methane reforming & 825 & 195 & 4.73 & 127 \\
& $\mathbf{8 7 5 ^ { \mathbf { a } }}$ & $\mathbf{2 3 8}$ & $\mathbf{5 . 1 7}$ & $\mathbf{7 7}$ \\
\hline & 925 & 256 & 5.25 & 121 \\
\hline a. Optimum HTGR ROT for steam methane reforming; nearly all the HTGR heat is used to generate hydrogen. & \\
\hline
\end{tabular}




\section{DISCUSSION}

The NGNP project evaluated the impact that increasing the HTGR ROT from $650-950^{\circ} \mathrm{C}$ would have on the primary output of an HTGR (process heat) and secondary outputs (electricity and hydrogen from either HTSE or steam methane reforming). The results were used to determine the optimum HTGR ROTs for each of these outputs as described in Table 7 and summarized as follows:

- The optimum ROT for process heat delivered as steam was $770^{\circ} \mathrm{C}$, but this temperature for hot helium was dependent on the temperature requirements of the process

- The optimum ROT for electricity generation was $950^{\circ} \mathrm{C}$, the maximum temperature assessed in this study

- The optimum ROT for hydrogen production via HTSE were $950^{\circ} \mathrm{C}$ for electricity generation and $850^{\circ} \mathrm{C}$ for process heat; both HTGR outputs are required for HTSE

- The optimum ROT for hydrogen production via steam methane reforming was $875^{\circ} \mathrm{C}$.

Table 7. Optimum ROTs for primary and secondary outputs from an HTGR.

\section{Primary HTGR Outputs Optimum HTGR} (Process Heat) ROT $\left({ }^{\circ} \mathrm{C}\right)$

Comments

High-Temperature Steam $770^{\circ} \mathrm{C} \quad$ A higher ROT will not increase the maximum flow rate delivered at $540^{\circ} \mathrm{C}$ and of steam delivered at $540^{\circ} \mathrm{C}$ and $17 \mathrm{MPa}$. The optimum $17 \mathrm{MPa}$ ROT will vary depending on the supplied steam temperature and pressure.

High-Temperature Helium varies delivered at $625-925^{\circ} \mathrm{C}$ and 7-9 $\mathrm{MPa}$

Secondary HTGR Outputs

Electricity generated by a $950^{\circ} \mathrm{C}$ generic power cycle The optimum ROT depends on the temperature requirements of the process that utilizes the heat.

$\begin{array}{ll}\text { Hydrogen via HTSE } & 850^{\circ} \mathrm{C} \text { for process } \\ & \begin{array}{l}\text { heat, } 950^{\circ} \mathrm{C} \text { for } \\ \text { electricity }\end{array}\end{array}$

The electricity production efficiency of a generic power cycle increases from $43.2-48.2 \%$ as the ROT varies from $650-950^{\circ} \mathrm{C}$.

The ROT for generating process heat depends on the operating temperature of the HTSE process, which is $800^{\circ} \mathrm{C}$. Electricity generation efficiency is greatest at $950^{\circ} \mathrm{C}$, the maximum temperature considered in this study.

Hydrogen via Steam $\quad 875^{\circ} \mathrm{C}$ The optimum ROT varies from $790-880^{\circ} \mathrm{C}$ depending on

Methane Reforming the desired composition of the product off-gas.

\subsection{Implications of Optimum ROTs on HTGR-Integrated Industrial Processes}

The results of the temperature sensitivity study indicate that optimum ROTs or a range of ROTs could be identified to further refine the process evaluations that were developed for HTGR-integrated production of synthetic transportation fuels, ammonia and ammonia derivatives, oil from unconventional sources, and substitute natural gas from coal. The evaluations were based on using an HTGR ROT of $750^{\circ} \mathrm{C}$ for the primary and secondary outputs (see References $2-8$ ). 
The preliminary estimates of the optimum ROTs for these industrial processes are summarized in this section. In all cases, additional work is needed to identify the optimum HTGR ROT or range of optimum ROTs and to evaluate their preliminary economics.

\subsubsection{Processes that Use Steam}

Detailed evaluations of HTGR-integrated production processes for recovering bitumen from oil sands and oil from oil shale were developed for processes that use natural gas based on an HTGR ROT of $750^{\circ} \mathrm{C}$. Based on the results of the temperature-sensitivity analysis, $770^{\circ} \mathrm{C}$ is the optimum HTGR ROT for generating superheated steam at $17 \mathrm{MPa}$, if supplied at $540^{\circ} \mathrm{C}$ as shown in Table 8 .

However, local site conditions and needs will determine the desirable steam conditions for bitumen and oil recovery operations, such as when HTGR-generated steam needs to be transported over significant distances before it is used. As a result, it would be beneficial to discuss specific site requirements with potential end users to determine whether steam delivery at $540^{\circ} \mathrm{C}$ and $17 \mathrm{MPa}$ meets their needs.

Table 8. Preliminary implications of the optimum HTGR ROTs required to produce steam and generate electricity for oil and bitumen recovery.

\begin{tabular}{|l|l|l|l|}
\hline $\begin{array}{l}\text { HTGR-Integrated } \\
\text { Processes }\end{array}$ & $\begin{array}{c}\text { Primary and } \\
\text { Secondary HTGR } \\
\text { Outputs Required }\end{array}$ & $\begin{array}{c}\text { Optimum HTGR } \\
\text { ROT }\left({ }^{\circ} \mathrm{C}\right)\end{array}$ & \multicolumn{1}{c|}{ Comments } \\
\hline $\begin{array}{l}\text { Oil recovery from } \\
\text { oil shale } \\
\begin{array}{l}\text { Bitumen recovery } \\
\text { from oil sands }\end{array}\end{array}$ & $\begin{array}{l}\text { Process heat supplied } \\
\text { as steam }\end{array}$ & $\begin{array}{l}770^{\circ} \mathrm{C} \text { (if steam is } \\
\text { supplied at } 540^{\circ} \mathrm{C} \text { and } \\
17 \mathrm{MPa}) \\
950^{\circ} \mathrm{C} \text { for electricity }\end{array}$ & $\begin{array}{l}\text { If the process requires steam } \\
\text { delivered at a different } \\
\text { temperature and pressure, the } \\
\text { optimum HTGR ROT will change. }\end{array}$ \\
\hline
\end{tabular}

\subsubsection{Processes that Use Methane Reforming}

Detailed evaluations of HTGR-integrated production processes for synthetic diesel, synthetic gasoline, and ammonia derivatives were developed for processes that use natural gas and require hydrogen from methane reforming based on an HTGR ROT of $750^{\circ} \mathrm{C}$. Synthetic gasoline and ammonia derivative processes use a two-step reformer-steam methane reforming and autothermal reforming - to produce hydrogen. Synthetic diesel production only uses autothermal reforming.

The optimum HTGR ROTs for the production of synthetic diesel, synthetic gasoline, and ammonia derivatives should be the minimum temperatures needed to support methane reforming for the particular plant configuration, as shown in Table 9. However, the actual HTGR ROT and heat requirements for the process will depend on a determination of the optimal heat recovery from methane reforming and other processes, which can supply the heat and power needs in other portions of the plant. After the energy crisis of the early 1970s, industrial process plants were pressured to maintain their profitability while facing rising energy costs. Some companies were unsuccessful and went out of business, but others increased their profitability by improving their overall energy efficiency. In 1970, for example, the synthesis of ammonia required $40 \mathrm{GJ} / \mathrm{MT}$ (gigajoules per metric ton), but by 1999, improved heat integration and more efficient pumps and compressors had decreased the energy requirement for synthesis to $28 \mathrm{GJ} / \mathrm{MT}$. $^{18,19}$ 
Table 9. Highest assumed temperature provided with a maximum HTGR ROT of $750^{\circ} \mathrm{C}$ for processes that use methane reforming to produce synthetic diesel, synthetic gasoline, and ammonia derivatives.

\begin{tabular}{|l|c|c|l|}
\hline $\begin{array}{c}\text { HTGR-Integrated } \\
\text { Processes using } \\
\begin{array}{c}\text { Natural Gas for } \\
\text { Methane Reforming }\end{array}\end{array}$ & $\begin{array}{c}\text { Highest Assumed } \\
\text { Temperature of } \\
\text { HTGR-Provided } \\
\text { Heat } \\
\left({ }^{\circ} \mathrm{C}\right)\end{array}$ & $\begin{array}{c}\text { Required } \\
\text { HTGR } \\
\text { ROT } \\
\left({ }^{\circ} \mathrm{C}\right)\end{array}$ & \multicolumn{1}{c|}{ Comments } \\
\hline $\begin{array}{l}\text { Synthetic Diesel } \\
\text { Production }\end{array}$ & 650 & 700 & $\begin{array}{l}\text { Heat supplied by the HTGR is used to preheat } \\
\text { the natural gas feed to } 650^{\circ} \mathrm{C} \text {. Oxygen is added } \\
\text { to combust the methane and raise the auto- } \\
\text { thermal reforming temperature to } 1021^{\circ} \mathrm{C} .\end{array}$ \\
\hline $\begin{array}{l}\text { Synthetic Gasoline } \\
\text { Production }\end{array}$ & 739 & 789 & $\begin{array}{l}\text { Heat supplied by the HTGR is used primarily to } \\
\text { preheat the natural gas feed. }\end{array}$ \\
\hline $\begin{array}{l}\text { Ammonia } \\
\text { Derivatives } \\
\text { Production }\end{array}$ & 760 & 795 & $\begin{array}{l}\text { The initial detailed analysis utilized an HTGR } \\
\text { ROT of } 750^{\circ} \mathrm{C} \text {. If } 795^{\circ} \mathrm{C} \text { heat could be supplied } \\
\text { by the HTGR, that would be a better operating } \\
\text { temperature. }\end{array}$ \\
\hline
\end{tabular}

In a modern conventional natural gas-to-synthetic diesel plant, shown as a simplified block flow diagram in Figure 5, the heat recovered from the autothermal reformer and Fischer-Tropsch synthesis units is enough to generate more than enough electricity to meet all plant electrical power needs. The excess electrical power is sold to the grid and represents a significant revenue stream (see Reference 2). Energy efficiency is also achieved by burning some of the light gas product to generate the heat required for separating the crude products into diesel, naphtha, and light gases.

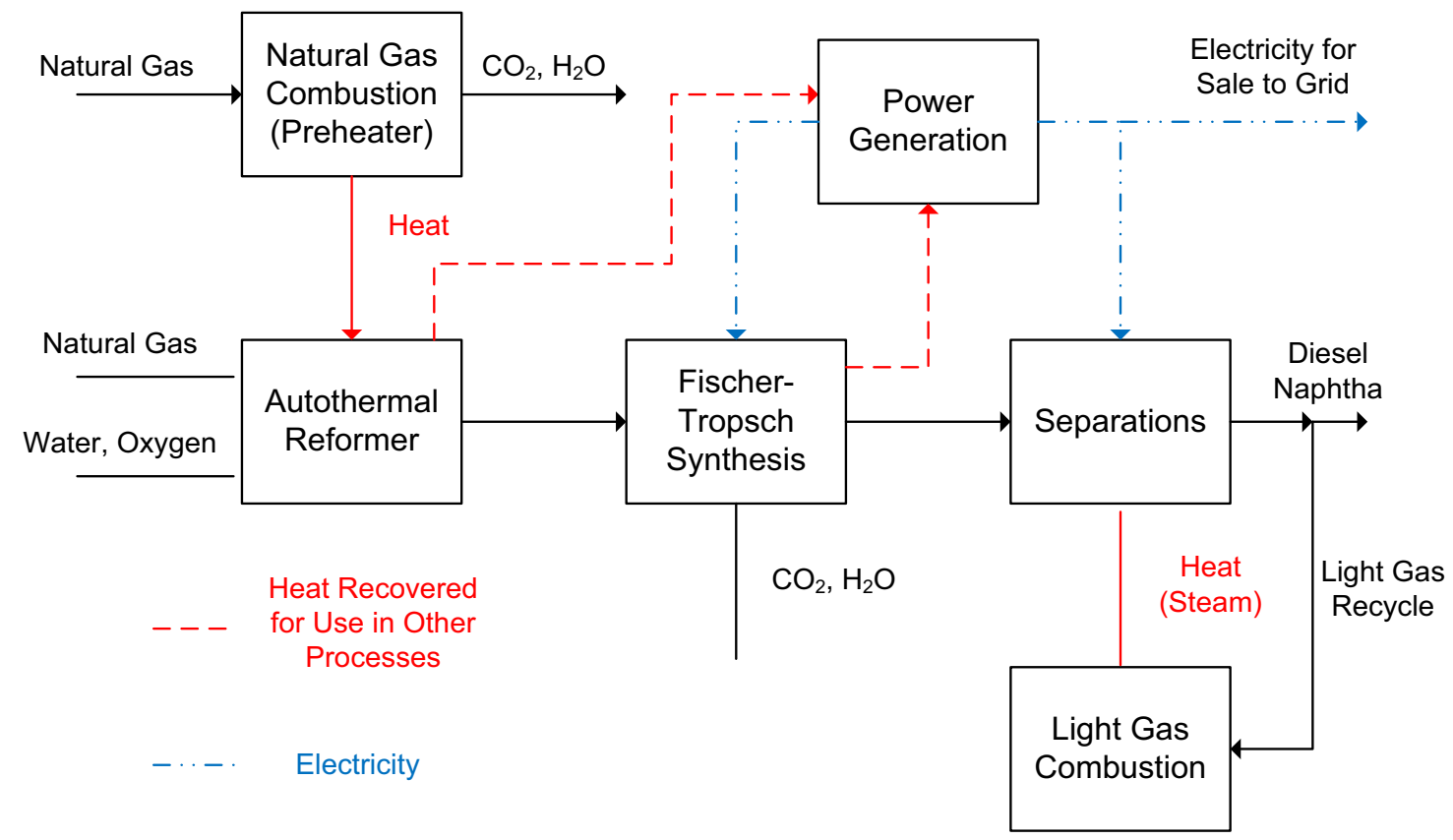

Figure 5. Simplified block flow diagram for a conventional natural gas-to-diesel process plant.

Based on the results of the temperature-sensitivity analysis, the optimum HTGR ROT for the production of synthetic diesel, synthetic gasoline, and ammonia derivatives would be the minimum temperature needed to support methane reforming for the particular plant configuration as shown in 
Table 9. For example, an HTGR-integrated synthetic diesel plant that incorporates significant heat integration, as shown in the block flow diagram in Figure 6, is estimated to require a maximum HTGR ROT of $750^{\circ} \mathrm{C}$. The HTGR is used to preheat natural gas and water to $650^{\circ} \mathrm{C}$. Oxygen is added to combust some of the methane in the natural gas so the autothermal reforming process reaches a suitable operating temperature. Energy efficiency is achieved by using heat left over from the autothermal reformer and the Fischer-Tropsch synthesis units to generate electricity.

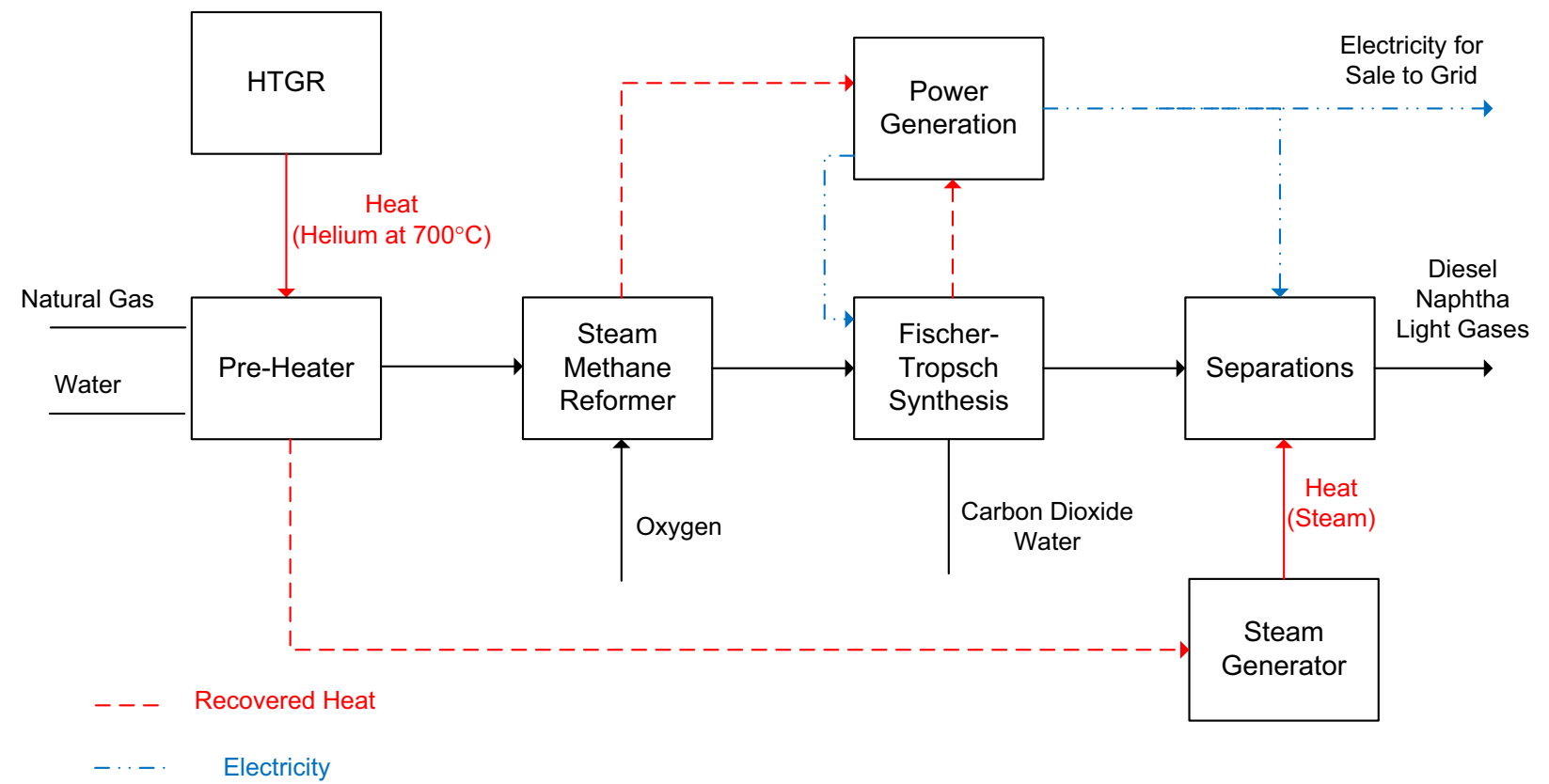

Figure 6. Simplified block flow diagram for an HTGR-integrated natural gas-to-synthetic diesel industrial process plant.

It would be beneficial to discuss specific plant configurations with potential end users to determine the most desirable HTGR ROTs for their heat delivery needs.

\subsubsection{Processes that Utilize HTSE}

Detailed evaluations of HTGR-integrated production processes for synthetic diesel, synthetic gasoline, and substitute natural gas were developed for processes that use coal and require hydrogen from HTSE based on an HTGR ROT of $750^{\circ} \mathrm{C}$.

The optimum HTGR ROT for these processes is estimated to be $850^{\circ} \mathrm{C}$ for process heat and $950^{\circ} \mathrm{C}$ for electricity generation, as shown in Table 10, which corresponds precisely with the optimum ROT determined in the temperature-sensitivity analysis for hydrogen production via HTSE. Since HTSE requires an operating temperature of $800^{\circ} \mathrm{C}$, higher than the $750^{\circ} \mathrm{C}$ ROT assumed in the detailed process evaluations, natural gas combustion is required to provide topping heat.

The detailed evaluations did not consider hydrogen production via methane reforming, however the economic analyses may indicate that steam methane reforming is an economically viable alternative to HTSE. If so, optimum HTGR ROTs would also need to be determined for these processes.

Heat integration opportunities should also be considered. If these processes used reactive coal, additional heat integration opportunities could be achieved by gasifying the coal in a Lurgi or fixed bed coal gasifier at approximately $950^{\circ} \mathrm{C}$, which would correspond to an HTGR ROT of $975^{\circ} \mathrm{C}$. 
Table 10. The optimum HTGR ROTs for processes that use coal and use heat and hydrogen from HTSE for synthetic diesel, synthetic gasoline, and substitute natural gas production.

\section{HTGR-Integrated Processes}

utilizing Coal

Synthetic diesel production

Synthetic gasoline production

Substitute natural gas production

\section{Optimum HTGR ROT $\left({ }^{\circ} \mathrm{C}\right)$}

$850^{\circ} \mathrm{C}$ for process heat supplied If reactive coal is used, gasification as steam to the HTSE process $950^{\circ} \mathrm{C}$ for electricity generation) could be done at $950^{\circ} \mathrm{C}$ in a Lurgi or fixed-bed gasifier, which would correspond to an HTGR ROT of $975^{\circ} \mathrm{C}$

\subsubsection{Summary-Optimum HTGR ROT for Industrial Processes}

The preceding section summarizes the estimated optimum ROTs or range of ROTs for industrial processes that utilize heat, electricity, or hydrogen generated by an HTGR. As illustrated in Figure 7, the optimum ROTs further refine the estimated process temperature ranges that were determined in the detailed HTGR-integrated industrial process evaluations. ${ }^{20}$ The optimum HTGR ROT for processes that utilize high-temperature helium is $35-50^{\circ} \mathrm{C}$ higher than the maximum process temperature range to account for the two heat exchangers located between the HTGR and the process. The optimum HTGR ROT for processes that utilize steam is $770^{\circ} \mathrm{C}$. Additional modeling is required to provide a more precise estimate of the optimum ROTs; however, the exact optimum for each process is expected to be bound by the ranges that have already been determined.

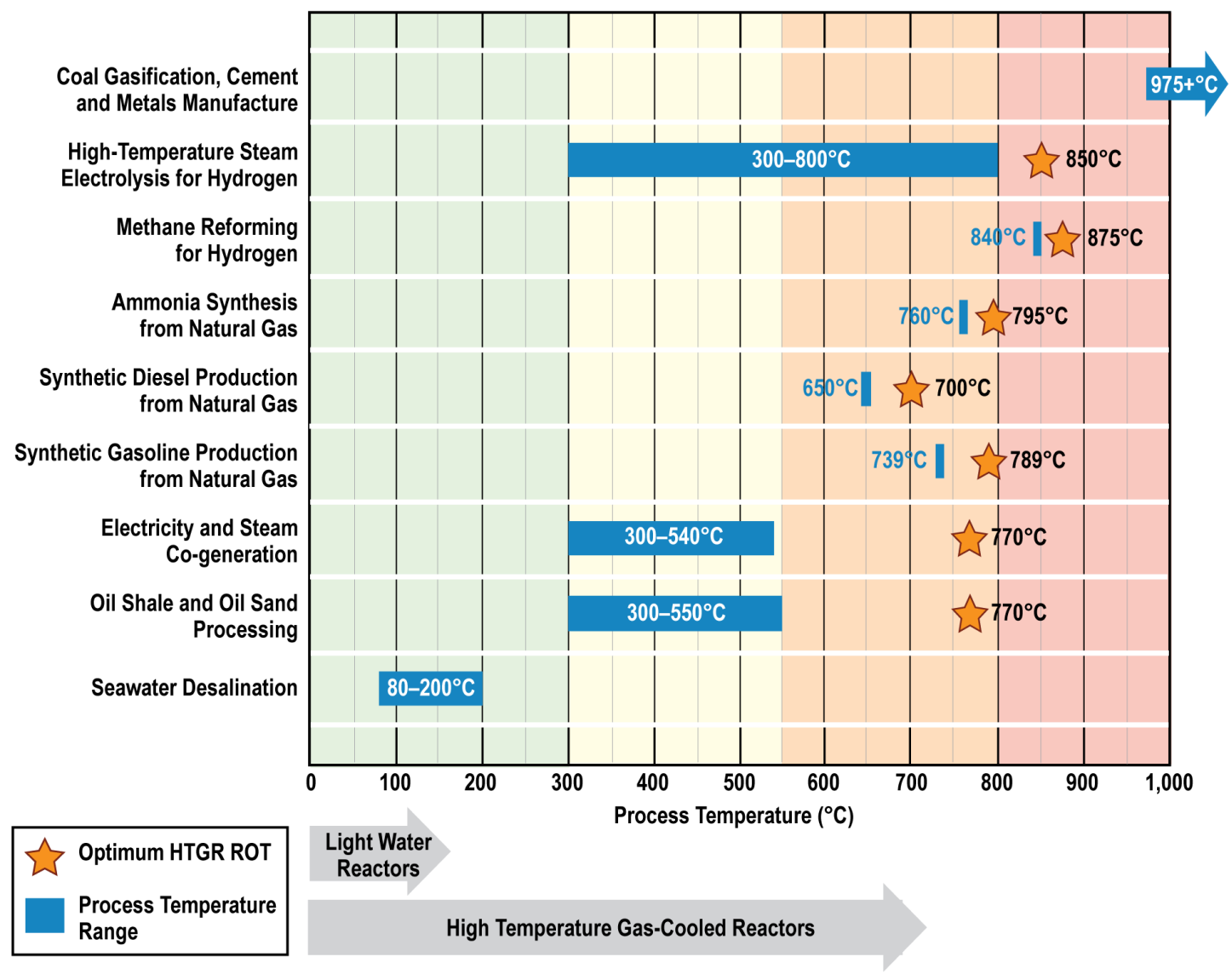

Figure 7. Optimum HTGR ROTs and the process temperature range associated with HTGRintegrated industrial processes. 


\section{CONCLUSIONS}

Based on the results of this study, it can be concluded that:

- The optimum HTGR ROTs for steam generation (delivered at $540^{\circ} \mathrm{C}$ and $17 \mathrm{MPa}$ ), electricity generation, hydrogen production via $\mathrm{HTSE}$, and hydrogen production via steam methane reforming are $770^{\circ} \mathrm{C}, 950^{\circ} \mathrm{C}, 850^{\circ} \mathrm{C}$, and $875^{\circ} \mathrm{C}$, respectively.

- The optimum HTGR ROT for steam production varies depending on the temperature and pressure of the steam produced.

- The optimum HTGR ROT for process heat delivered as helium (or other hot gas) does not exist, because the optimum is process dependent.

- The results of the temperature-sensitivity analyses have implications for the detailed HTGRintegrated industrial process evaluations that use the primary and secondary outputs studied in this report and suggest that there is an optimum HTGR ROT for these industrial processes.

- Because this study was based solely on mass and energy balance information from the industrial processes, economic analyses are required to identify more realistic optimum HTGR ROTs.

- In the future, a more detailed study regarding the optimum HTGR ROT should include impacts of reactor operation, core physics, and mechanistic source term considerations, as well as the industrial process applications. It is likely that a coupled analysis would serve to further optimize both the RIT and the ROT for industrial applications of interest.

- In order to perform an economic analysis, the HTGR cost as a function of configuration, size, and temperature is required.

- Reactor suppliers should consider increasing the RIT relative to the ROT to better suit process heat applications.

\section{RECOMMENDATIONS FOR FUTURE WORK}

The following recommendations for future work are based on the results of this study:

- There are obvious technical advantages to increasing the HTGR ROT up to $950^{\circ} \mathrm{C}$. Similar work has been completed to evaluate the economics of the increasing HTGR ROT, however the results are based on a constant HTGR cost estimate. To improve the accuracy of the economic evaluation, it is recommended that a cost estimate for the HTGR be evaluated as a function of configuration, size, and HTGR ROT of $750-950^{\circ} \mathrm{C}$.

- There are obvious advantages of increasing the HTGR ROT for generating primary and secondary outputs, but for the past 2 years, the NGNP Project has been performing evaluations assuming an HTGR ROT of $750^{\circ} \mathrm{C}$. It is recommended that the previous detailed analyses for production of synthetic transportation fuels, co-generation of steam and electricity, and ammonia synthesis be reevaluated at higher HTGR ROTs to determine if improved process efficiency and economics would result. It is also recommended that higher HTGR ROTs be considered as future evaluations are conducted. 


\section{REFERENCES}

1. MPR-3181, "Survey of HTGR Process Energy Applications, Prepared by MPR Associates Inc.," MPR Associates, May 2, 2008.

2. TEV-667, "Nuclear-Integrated Methanol-to-Gasoline Production Analysis," R. Wood, May 11, 2010.

3. TEV-672, "Nuclear-Assisted Coal and Gas to Liquids Production Analysis," A. Gandrik, May 15, 2010.

4. TEV-666, "Nuclear-Integrated Ammonia Production Analysis," R. Wood, May 25, 2010.

5. TEV-704, "Nuclear-Integrated Oil Sands Recovery via Steam-Assisted Gravity Drainage,” A. Gandrik, V. Maio, May 15, 2010.

6. TEV-1029, "Integration of HTGRs to an In Situ Oil Shale Operation," E. Robertson, M. McKellar, November 18, 2010.

7. TEV-1091, "Integration of HTGRs and an Ex Situ Oil Shale Retort," E. Robertson, M. McKellar, December 13, 2010.

8. TEV-671, "Nuclear-Assisted Substitute Natural Gas Production Analysis," A. Gandrik, May 15, 2010.

9. TEV-674, "Power Cycles for the Generation of Electricity from a Next Generation Nuclear Plant," M. McKellar, May 15, 2010.

10. TEV-693, "Nuclear-Integrated Hydrogen Production Analysis,” M. McKellar, May 15, 2010.

11. TEV-953, "HTGR-Integrated Hydrogen Production via Steam Methane Reforming (SMR) Process Analysis," R. Wood, September 15, 2010.

12. TEV-954, "HTGR-Integrated Hydrogen Production via Steam Methane Reforming (SMR) Economic Analysis," R. Wood, September 15, 2010.

13. TEV-961, "Sensitivity of Hydrogen Production via Steam Methane Reforming to High Temperature Gas-Cooled Reactor Outlet Temperature Process Analysis," R. Wood, September 15, 2010.

14. TEV-962, "Sensitivity of Hydrogen Production via Steam Methane Reforming to High Temperature Gas-Cooled Reactor Outlet Temperature Economic Analysis,” R. Wood, September 15, 2010.

15. TEV-981, "An Analysis of the Effect of Reactor Outlet Temperature of a High Temperature Reactor on Electric Power Generation, Hydrogen Production, and Process Heat," M. McKellar, September 14, 2010.

16. TEV-988, "Sensitivity of HTGR Heat and Power Production to Reactor Outlet Temperature, Economic Analysis,” A. Gandrik, M. McKellar, September 17, 2010.

17. TEV-994, "Hydrogen Production via HTSE, Sensitivity to HTGR Reactor Outlet Temperature, Economic Analysis,” A. Gandrik, M. McKellar, September 17, 2010.

18. S. Nand and M. Goswami, "Energy Efficiency Gains in Indian Ammonia Plants Retrospect and Prospects, The Fertilizer Association of India 10, Shaheed Jit Singh Marg, New Delhi, 110067, India.

19. T. Gerlagh and A.W.N. van Dril, "The Fertilizer Industry and its Energy Use, Prospects for the Dutch Energy Intensive Industry,” January 1999, ECN-C—99-045.

20. "Evaluation of Alternative HTGR Technology Applications," General Atomics, December 23, 2010, NGNP-R00017. 